\title{
EFFECT OF TEMPERATURE ON PERCENTAGE OF GERMINATION OF CANISTEL SEEDS (Pouteria campechiana)
}

\author{
RENATA APARECIDA DE ANDRADE ${ }^{2}$, ANTONIO BALDO GERALDO MARTINS ${ }^{3}$, ISABELE SARZI ${ }^{4}$
}

\begin{abstract}
The canistel is a fruit originated in Mexico and Central America, being introduced in Brazil in 1986. The plants present medium size, however it can reach up to 15 meters of height; the leaves measure about 10 to $25 \mathrm{~cm}$; the flowers are complete and small and the fruit presents yellow coloration when ripe, with whitish pulp and sweet flavor. The propagation can be realized by seed or grafting.

In view of almost total absence of information about the culture and the possibility to have a commercial cultivation, the present work, was live in which the effect of the temperature was evaluated in the percentage of germination of the seeds. It was checked that the best averages were obtained in temperature of $30^{\circ} \mathrm{C}$ and the minor in $15^{\circ} \mathrm{C}, 20^{\circ} \mathrm{C}$ and $40^{\circ} \mathrm{C}$ could be considerate the worst of them.
\end{abstract}

Index terms: Pouteria campechiana, germination, seeds.

\section{EFEITO DA TEMPERATURA NA PORCENTAGEM DE GERMINAÇÃO DE SEMENTES DE CANISTEL (Pouteria campechiana) $^{1}$}

RESUMO - O canistel é uma fruteira originada no México e América Central, sendo introduzida no Brasil em 1986. As plantas apresentam porte médio, porém podem atingir até 15 metros de altura; as folhas medem cerca de 10 a $25 \mathrm{~cm}$; as flores são completas e pequenas, e o fruto apresenta coloração amarela quando maduro, com polpa esbranquiçada e sabor doce. A propagação pode ser realizada por semente ou por enxertia.

Em vista da quase total ausência de informações sobre a cultura e a possibilidade de cultivo comercial, realizou-se o presente trabalho, no qual se avaliou o efeito da temperatura na porcentagem de germinação de sementes. Foi verificado que as melhores taxas foram obtidas à temperatura de $30^{\circ} \mathrm{C}$ e as menores a $15^{\circ} \mathrm{C}, 20^{\circ} \mathrm{C} \mathrm{e} 40^{\circ} \mathrm{C}$, sendo esta última a pior delas.

Termos para indexação: Pouteria campechiana, germinação, sementes.

\section{INTRODUCTION}

The canistel is a fruit originated in Mexico and Central America, being introduced in several tropical regions of the world (Benza, 1993). In Brazil that introduction was realized by UNESP-Campus of Jaboticabal, in 1986, with material that came from Florida, where it is planted at backyard orchards. The propagation, although is done a lot of times by seed, it can also be done by grafting, allowing the fixation of varieties (Donadio, 1998).

The plant presents medium size, however with great variation could reach up to 15 meters of height. The leaves are alternated, fine and measuring about 10 to $25 \mathrm{~cm}$ of length. The flowers are complete and small, happening among the leaves of the newest branches and they are usually produced in the rainy season. The fruit can vary of color, but commonly it is yellow when ripe, with whitish pulp and sweet flavor and when it is green has abundant amount of latex. The ocurrence of seeds on fruit can be just a little or several of them, which are black with 1 to 2 cm of size.

The good climatic conditions for its cultivation are in tropical climates of low altitude to the subtropical ones with $1800 \mathrm{~m}$ of altitude and frequent rains. It survives in medium low temperatures from 6 to $8^{\circ} \mathrm{C}$.

In view of almost total absence of information about this fruit, the present work, was realized having as objective to evaluate the effect of the temperature in the percentage of germination of canistel seeds to obtain the largest possible number of seedlings.

\section{MATERIALANDMETHODS}

The experiment was conduced in the Laboratory of Seeds, located in the Department of Vegetable Production, of Faculdade de Ciências Agrárias e Veterinárias - UNESP - Jaboticabal - Campus.

The treatments were constituted by six temperatures: $15^{\circ} \mathrm{C}, 20^{\circ} \mathrm{C}$, $25^{\circ} \mathrm{C}, 30^{\circ} \mathrm{C}, 35^{\circ} \mathrm{C}$ and $40^{\circ} \mathrm{C}$, writh four repetitions for each one of them and writ 10 seeds by repetition. It was used germinators model BOD MA 402 .

The seeds were extracted from ripe fruits of canistel trees, washed, placed to dry on shade and then conditioned in recipients simi- lar to the box type gerbox, having as substrate vermiculita with medium texture. It was done daily evaluation of the number of germinated seeds, in such way that the results were counted in periods of seven days, reaching a total of fourteen weeks in the end of the experiment. The values obtained were compared by average test, more specifically the test of Tukey with $5 \%$ of probability.

\section{RESULTS AND DISCUSSION}

Observing the Figures 1 and 2 is possible to verify that the best temperature for canistel germination is $30^{\circ} \mathrm{C}$, where $89,42 \%$ of the seeds germinated (Tab.1), with a higher germination speed, which allowed it to reach the maximum germination in the smallest time (9th week). In the 6th week it already presented more than $70 \%$ of germinated seeds, while this same rate was only reached in the 8 th week for the treatment of $35^{\circ} \mathrm{C}$ and in the $11^{\text {th }}$ for the treatment of $25^{\circ} \mathrm{C}$. However, there was no significant difference between the treatment of $30^{\circ} \mathrm{C}$ and the treatments of $35^{\circ} \mathrm{C}$ and $25^{\circ} \mathrm{C}$, which also presented a good percentage of germination of the seeds.

TABLE 1 - Difference by the average of the $\%$ of germination obtained when the seeds was maintained on the temperatures in study.

\begin{tabular}{|c|c|}
\hline Treatment & $\%$ germination \\
\hline $30 \mathrm{C}$ & 89,42 A \\
\hline $35 \mathrm{C}$ & $75,49 \mathrm{~A}$ \\
\hline $25 \mathrm{C}$ & 63,05 A \\
\hline $15 \mathrm{C}$ & $24,51 \quad$ B \\
\hline $20 \mathrm{C}$ & 21,79 \\
\hline $40 \mathrm{C}$ & 4,06 \\
\hline
\end{tabular}

Averages following by the same letter don't differ in statistic test of Tukey 5\% of probability.

Similar results were found by Barbosa et al. (1990) when they studied the influence of the temperatures of $20^{\circ} \mathrm{C}, 25^{\circ} \mathrm{C}$ and $30^{\circ} \mathrm{C}$ on seeds

1 (Trabalho 093/2002). Recebido: 28/06/2002. Aceito para publicação: 26/09/2002.

2 Eng. Agr., aluna de Pós-graduação em Agronomia - Produção Vegetal - UNESP - FCAV - Depto de Produção Vegetal. Via de acesso Prof. Paulo Donato Castellane, s/n. Cep: 14884-900. Jaboticabal/SP. Tel/Fax: (16)32092668. e-mail: reandrad@ fcav.unesp.br

3 Eng. Agr., Prof. Doutor - UNESP - FCAV - Depto de Produção Vegetal. e-mail: baldo@ fcav.unesp.br

4 Eng. Agr., aluna de Pós-graduação em Agronomia - Produção Vegetal - UNESP - FCAV - Depto de Produção Vegetal. e-mail: isasarzi@ fcav.unesp.br 
germination for cambuci (Paivaea langsdorfii Berg) and uvaia (Eugenia uvalha Meng). They observed that the best temperature for seeds and velocity of germination was the $30^{\circ} \mathrm{C}$.

In another research, Barbosa \& Barbosa (1985) studied the germination of wild fruits: wax jambu (Syzygium jambos), guamo (Inga edulis) and jatoba (Hymenaea stilbocarpa) in three temperatures $\left(20^{\circ} \mathrm{C}\right.$, $25^{\circ} \mathrm{C}$ and $30^{\circ} \mathrm{C}$ ) and they verified that the guamo seeds presented larger percentage and germination speed on the temperature of $30^{\circ} \mathrm{C}$; for the jatoba there was not significant difference between the temperatures of $25^{\circ} \mathrm{C}$ and $30^{\circ} \mathrm{C}$ and, for the wax jambu was not observed differences in relation to the tested temperatures.

Borges et al. (1998) realized an experiment testing the influence of four temperatures $\left(10^{\circ} \mathrm{C}, 20^{\circ} \mathrm{C}, 30^{\circ} \mathrm{C}\right.$ and $\left.40^{\circ} \mathrm{C}\right)$ on seeds germination for two variets of mango ('ubá' and 'espada') and verified that the temperature of $30^{\circ} \mathrm{C}$ favored the germination and the inicial embryo development for the two variets of mango in study.

The temperature of $15^{\circ} \mathrm{C}$ presented very low germination percentages in comparison with the others, being verified the same for the treatment with temperature of $20^{\circ} \mathrm{C}$ and $40^{\circ} \mathrm{C}$, being the last one considered as the worst temperature, due to the extremely low rate of verified germination. The treatments of $15^{\circ} \mathrm{C}$ and $20^{\circ} \mathrm{C}$ practically did not present any germination in the first weeks and, at the end, the reached rate was low. Although for the treatment of $40^{\circ} \mathrm{C}$ it was not observed any germination of the seeds during the whole period of the experiment.

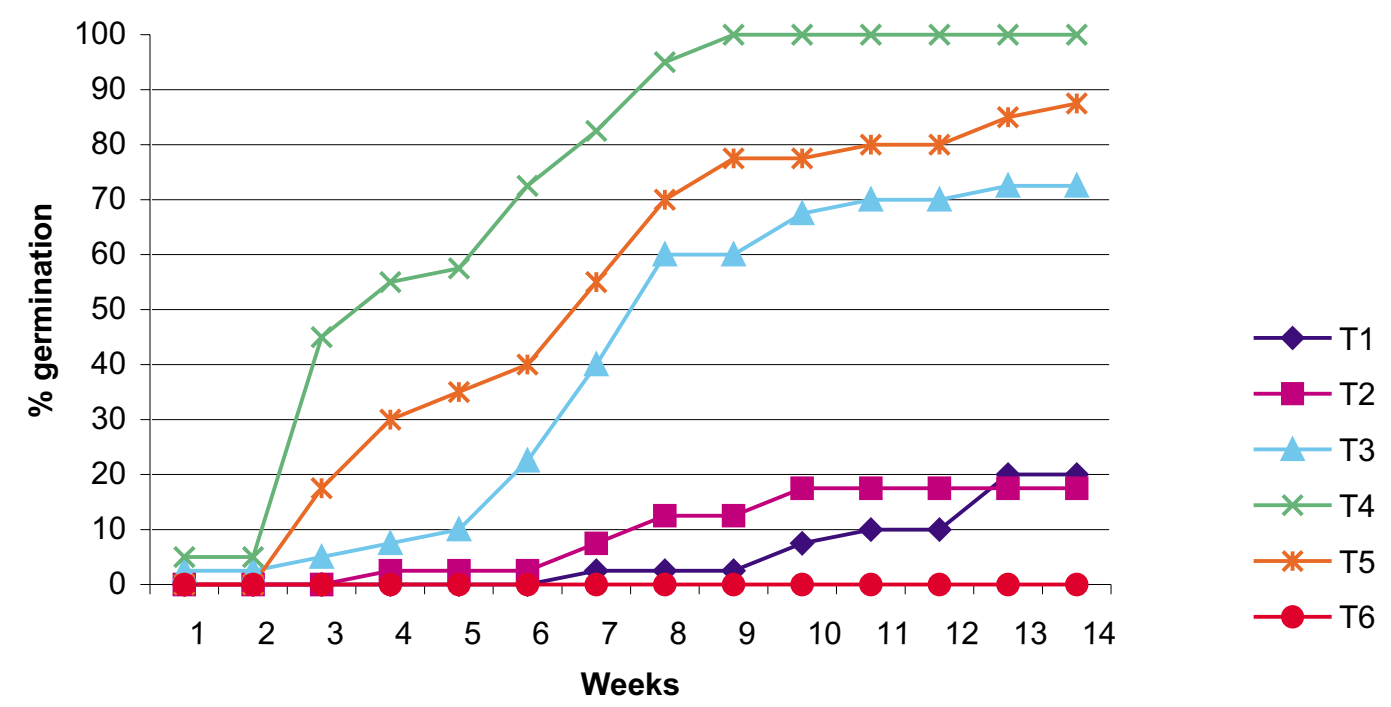

FIGURE 1 - Evolution of the percentages of germination evaluated by week, on different temperatures studied.

\section{CONCLUSION}

With base in the presented results it can be said that: - the temperature of $30^{\circ} \mathrm{C}$ is the best to germinate canistel seeds, reaching the highest percentages of germination and the minor time to get it, what have a real importance for the nurserymen.

\section{REFERENCES}

BARBOSA, J.M.; BARBOSA, L.M. Avaliação dos substratos, temperaturas de germinação e potencial de armazenamento de sementes de três frutíferas silvestres. Ecossistema. Pinhal, v.10. p.152-160. Outubro/1985.
BARBOSA, J.M.; BARBOSA, L.M.; SILVA, T.S.; FERREIRA, D.T.L. Influência de substratos e temperaturas na germinação de sementes de duas frutíferas silvestres. Revista Brasileira de Sementes. Brasília, v.12, n.2. p.66-73. 1990.

BENZA, J.C. 143 Frutales Nativos. Universidad Nacional Agraria La Molina, 1993.366 p.

BORGES, C.A.M.; SIQUEIRA, D.L.; DIAS, D.C.F.S.; CARDOSO, A.A. Influência do peso das sementes e da temperatura sobre a germinação e crescimento de plântulas de mangueiras 'espada' e 'ubá'. Revista Brasileira de Fruticultura, Cruz das Almas. v.20, n.3. p.272282. Dezembro/1998.

DONADIO, L.C.; NACHTIGAL, J.C.; SACRAMENTO, C.K. Frutas Exóticas. Jaboticabal: FUNEP, 1998. 279 p. 